\title{
Glucocorticoid Sensitivity in Mood Disorders
}

\author{
A.T. Spijker $^{\mathrm{a}}$ E.F.C. van Rossum ${ }^{\mathrm{b}}$ \\ a Department for Mood Disorders, PsyQ The Hague, The Hague, and b Department for Endocrinology, \\ Erasmus Medical Center Rotterdam, Rotterdam, The Netherlands
}

\section{Key Words}

Glucocorticoid sensitivity - Glucocorticoid receptor • Mineralocorticoid receptor $\cdot$ Cortisol-releasing hormone receptor- $1 \cdot$ Polymorphisms $\cdot$ Mood disorders $\cdot$ Cortisol awakening rise $\cdot$ Scalp hairs $\cdot$ Childhood adversity

\begin{abstract}
In this review, we provide an overview of recent literature on glucocorticoid (GC) sensitivity in mood disorders. Assessing GC sensitivity is often performed by measuring the cortisol awakening rise (CAR), by challenging the hypothalamic-pituitary-adrenal (HPA) axis using a dexamethasone suppression test (DST) or a dexamethasone/cortisol-releasing hormone test (DEX/CRH); more recently by measuring cortisol as a retrospective calendar in scalp hair. The main findings in mood disorders are higher mean cortisol levels in hair samples and a higher CAR, showing a hyperactivity of the HPA axis. This is in line with the mild resistance for GCs previously observed in challenge tests during mood episodes. GC sensitivity is partly determined by polymorphisms in the genes encoding receptors and other proteins involved in the regulation of the HPA axis. We shortly discuss the glucocorticoid receptor, as well as the mineralocorticoid receptor, the cortisol-releasing hormone receptor-1, and the glucocorticoid receptor co-chaperone FKBP5. Data clearly indicate genetic changes, along with epigenetic changes which influence the set-point and regulation of the HPA axis. Early trauma, as well as influences in utero, appears to be important. Future research is necessary to further clarify the biological background and consequences of an individual's cortisol exposure in relation to mood.

Copyright $\odot 2011$ S. Karger AG, Basel
\end{abstract}

\section{Introduction}

During daily life, mood is known to be largely influenced by circadian rhythms and stress. An individual's risk to develop a mood disorder can depend on one or a combination of factors including vulnerability, defined by genetics, early life stress, and consequences of life events. The biological stress response has an important function in coping with life events, and differs between individuals with a genetically and epigenetically determined set-point during youth. The key systems in the stress response are regulated by fast adrenergic neurotransmitters (the sympathetic nervous system) and slower glucocorticoid hormones (the hypothalamic-pituitary-adrenal (HPA) axis), of which cortisol is the main hormone in humans. It is complex to properly measure and assess the functioning of the HPA axis in humans. However, it is important to evaluate the role of the stress response and hence the flexibility of the individual to cope with physical and mental changes in life in order to identify risk factors defining health and disease. In addition, an individual's level of chronic cortisol exposure in brain areas related to affection and cognition may be very important in mood disorders. Aside from the stress system reactivity, it is also important to mention the consequences of absolute high and low cortisol levels. The consequences of absolute high cortisol levels are best observed in the clinically well-known Cushing's syndrome, where cortisol levels are usually extremely high due to exogenous or endogenous causes. These symptoms can vary between physical symptoms, for example weight gain, increase abdominal fat, hyperhidrosis and hirsut-

\section{KARGER}

Fax +4161306 1234

E-Mail karger@karger.ch

www.karger.com
(C) 2011 S. Karger AG, Basel

0028-3835/12/0953-0179\$38.00/0

Accessible online at:

www.karger.com/nen
Anne T. Spijker

PsyQ The Hague

Department for Mood Disorders, Lijnbaan 4

NL-2512 VA The Hague (The Netherlands)

Tel. +31 703916300 , E-Mail a.spijker@psyq.nl 
ism, and psychiatric symptoms, for example manic and depressive episodes, psychosis and anxiety. Also hypocortisolism as seen in morbus Addison can have serious consequences on mental health, making patients vulnerable to mood disorders and anxiety.

Cortisol is known to exert its effect through two receptors: the glucocorticoid receptor (GR) and the mineralocorticoid receptor (MR). Both receptors are also present in the brain. The GR is found throughout the brain, with a very high density in the hippocampus, the prefrontal cortex (PFC), the paraventricular nucleus of the hypothalamus, the amygdala and the dentate gyrus. The MR is predominantly found in the hippocampus, the PFC and the amygdala [1]. The GR is known to be an important regulator during the acute stress response, while both GR and MR are active under basal conditions. Both corticosteroid receptors are co-expressed in the limbic system, and it seems obvious that both receptor systems have a balanced function in regulating the stress response [2]. FKBP5, a co-chaperone of the GR, also influences GR activity [3]. Finally, the cortisol-releasing hormone receptor-1 (CRHR1) is important in initiating the stress response.

\section{Assessment of Glucocorticoid Sensitivity in Relation to Mood}

Functional evaluation of the HPA axis is complex. The HPA axis is characterized by daily rhythms, seasonal rhythms, and pulsation leading to varying cortisol levels in blood and saliva. The two most common approaches to evaluate HPA axis functioning are the measurement of basal cortisol levels in response to awakening, as a model for an endogenous stress response; and the measurement of the HPA axis functioning during challenging conditions, which gives an impression about the reactivity of the stress response itself. This measurement is characterized by negative feedback at the pituitary level on the production of adrenocorticotropic hormone (ACTH), and hence by diminished stimulation of the cortisol production in the adrenal glands.

\section{The Cortisol Awakening Rise}

It is best to collect samples immediately upon waking to evaluate the cortisol awakening rise (CAR), which reflects the natural response to awakening with an increase in cortisol levels of $50-75 \%$ within half an hour after awakening [4]. Several influences on the CAR are defined by Vreeburg et al. [5], including sleep patterns (duration, awakening time), season of sampling, activities (working day, physical activity) and health indicators (smoking, cardiovascular disease, physical activity). Also psychosocial stressors and job stress have been found to result in higher CARs, whereas exhaustion and burnout resulted in lower CARs [6].

In patients with mood disorders, a higher CAR was observed in both remitted $(\mathrm{n}=579)$ and currently depressed $(n=701)$ patients [7]. In acutely depressed outpatients, cortisol levels were $25 \%$ higher compared with healthy controls [8]. In addition to this finding, a study among 230 late adolescents revealed that a higher CAR was predictive for developing a major depressive disorder (MDD) within a year after sampling [9]. In addition, subjects without a history of depression but with parents diagnosed with MDD had higher CARs, which were equal to the subjects with a current depression [10]. It seems that these findings reflect higher basal cortisol levels as a trait phenomenon irrespective of current status.

\section{Challenging the HPA axis}

The dexamethasone suppression test (DST) is a neuroendocrine test measuring GR-mediated negative feedback. This test consists of a low-dose administration (1 mg or $0.25 \mathrm{mg}$ ) of dexamethasone, a synthetic glucocorticoid hormone, at 11 p.m. and the measurement of cortisol levels the following morning. Due to the negative feedback action at the pituitary and hypothalamic levels, subsequent cortisol levels are suppressed the next day. Nonsuppression of cortisol levels after dexamethasone indicates GR resistance. The strength of cortisol suppression reflects the negative feedback mechanism, which is largely variable between but rather stable within individuals [11]. The test is very easy; however, an important restriction to consider for use in psychiatry is the limited sensitivity in studying MDD [12]. Particularly in outpatients, the sensitivity is low. It was reported that only $12 \%$ of outpatients with nonmelancholic depression showed nonsuppression in the DST, while $64 \%$ patients with psychotic depression showed nonsuppression [12]. Low percentages of nonsuppression after 1-2 mg dexamethasone in moderately depressed patients (44\%) were found, in contrast with severely depressed psychotic patients and bipolar patients (67-78\%) [13]. Heuser et al. [14] developed the combined DEX/Cortisol Releasing Hormone test (DEX/CRH test) as a refinement of the DST. This challenge test consists of administration of $1.5 \mathrm{mg}$ dexamethasone at 11:00 p.m. followed by administration of $100 \mu \mathrm{g} \mathrm{CRH}$ at 3 p.m. on the next day. Cortisol and ACTH levels are sampled every 15 min from 2 p.m. until 6 p.m. 
This test was found to be more sensitive for MDD (about $80 \%$ ), and is even above $90 \%$ when the cohort was stratified for age.

However, the DEX/CRH test is more intrusive for patients, which limits the use in research among large cohorts of outpatients. Zobel et al. [15] found that in a cohort of 74 remitted patients, the DEX/CRH test was able to predict relapse of depression within 6 months. In patients with a relapse within 6 months after discharge, there was a 4- to 6-fold increased cortisol response in the DEX/CRH test just before discharge. Appelhof et al. [16] found in a sample of 45 outpatients with remitted major depression that higher cortisol levels in the DEX/CRH test were associated with relapse, which was confirmed by Ising et al. [17]. Rybakowski's group [84] also stressed that the number of episodes was associated with more non-suppression. Bipolar patients in the same study were found to have most non-suppression when compared with healthy controls and unipolar depressed patients in remission. Watson et al. [18] confirmed that in bipolar patients, cortisol levels in response to the DEX/CRH test are increased, with no difference between a current depressive episode and remission.

The issue whether this is a state or trait phenomenon is not yet solved. The studies including healthy family members suggest that hyperactivity of the HPA axis is not only a reflection of current mood state [19]. A new approach to this problem is the scar theory [20], describing long-lasting changes in the function of the brain (cognition, biological) following depression, increasing the risk for developing future depressive episodes. The premorbid regulated 'set-point' of the HPA axis is thought to be changed through depression by, for example, epigenetic changes in DNA methylation in depressed suicide victims [21] and children of mothers who were depressed during pregnancy [22]. This scarring process is possibly a structural phenomenon developed during life. Later, we will briefly discuss the influence of early life trauma on epigenetic phenomena.

\section{Cortisol in Scalp Hairs}

A novel and noninvasive parameter is measuring cortisol in scalp hair. Hair grows with an average of $1 \mathrm{~cm}$ per month, and it has been shown that cortisol can be reliably measured in hair [23-25]. The use of hair provides the opportunity to measure long-term cortisol levels (reflecting mean levels of the past months) in an easy way without limitations caused by the pulsatility and circadian rhythm of cortisol or acute circumstances. Strong correlations of hair cortisol have been observed with tissue effects of cor- tisol in healthy individuals (e.g. waist circumference), as well as with cortisol exposure in patients with hyper- or hypocortisolism [25]. This method has only preliminary been applied in psychiatry. Steudte et al. [26] found a decreased cortisol level in patients with generalized anxiety disorder. Our group recently found that cortisol levels were increased in patients with $\mathrm{BD}$ when having a co-morbid psychiatric diagnosis [27]. Interestingly, hair cortisol levels were decreased when patients with $\mathrm{BD}$ were also diagnosed with panic disorder. Moreover, we found an association of higher hair cortisol levels with adult onset (older than 30 years) of $\mathrm{BD}$, and impaired executive functioning, compared to patients with puberty onset, normal executive functioning and normal cortisol levels [28].

\section{Genetics of HPA Axis: Consequences for Physical and Mental Health}

\section{GR Polymorphisms: Physical Health}

There are several known genetic variations in the GR Gene NR3C1 with consequences for cortisol sensitivity [29]. Subtle changes in cortisol signaling leading to relative resistance or hypersensitivity for glucocorticoids (GCs) can have long-term consequences. It is known that these changes can affect metabolic and inflammatory status and body composition. Cognitive performance and mental health can also be influenced by altered HPA axis regulation.

Haplotype 4 (TthIIII $+9 \beta)$ and haplotype 5 (TthIIII + $9 \beta+\mathrm{ER} 22 / 23 \mathrm{EK})$ are both associated with a relative resistance for GCs [30-33]. The ER22/23EK polymorphism is associated with a healthy metabolic and inflammatory profile, characterized by lower total cholesterol and lowdensity lipoprotein cholesterol levels as well as lower fasting insulin concentrations, a better insulin sensitivity and lower C-reactive protein levels [31, 34]. This GR variant is also associated with a beneficial body composition, shown by young male ER22/23EK carriers (taller, stronger and more muscle mass than noncarriers) and female ER22/23EK carriers (tendencies for smaller waist and hip circumferences, lower body weight [35], and protective effect on weight gain during pregnancy $[32,36])$. These associations of the ER22/23EK polymorphism are in line with a mild GR resistance. The clinical data are supported by in vitro experiments showing reduction of transactivating capacity in transfection experiments and in peripheral blood mononuclear lymphocytes of carriers of this polymorphism [37]. In addition, the underlying molecular mechanism of the GR gene variant has been revealed [38]. 
The $9 \beta$-polymorphism seems to increase the stability of mRNA of GR- $\beta$, an alternative splice variant of the GR gene [30]. GR- $\beta$ is thought to exert a dominant negative effect on the active GR- $\alpha$. The association of the $9 \beta$ polymorphism and the immune system has been shown by the higher risk of developing rheumatoid arthritis in carriers [30, 39]. Patients with multiple sclerosis have been found to have a more aggressive course of disease when they carry at least one allele of haplotype 5 (TthIIII $+9 \beta$ + ER22/23EK), which is possibly related with an altered inflammatory state due to GC resistance [40]. Interestingly, in 2008 van den Akker et al. [41] reported that the $9 \beta$ polymorphism is related to a more active proinflammatory system, and subsequently associated with the risk of cardiovascular disease. In line with these findings, the Heart and Soul Study showed that the $9 \beta$ SNP is associated with reduced heart function, partly mediated by low-grade inflammation [42].

Haplotype $2(B c l \mathrm{I})$, haplotype $3($ TthIIII $+B c l \mathrm{I})$ and haplotype $6(\mathrm{~N} 363 \mathrm{~S})$ have all been associated with a relative hypersensitivity to GCs and clinical signs of hypersensitivity to cortisol in various tissues [43]. Carriers of $\mathrm{N} 363 \mathrm{~S}$ have in addition to increased cortisol suppression also an increased insulin response in the DST, a tendency towards lower bone mineral density, and increased BMI [32]. Although other studies have reported associations with increased BMI, as expected as a result of glucocorticoid hypersensitivity, these findings have not been consistently confirmed $[29,44]$. The $B c l$ I polymorphism has been found to be associated with abdominal obesity [32], lower bone mineral density [45] and unhealthy body composition in young boys [46].

\section{GR Polymorphisms: Mental Health}

Recently, we reviewed the GR and MR SNPs in relation to mood disorders [47]. The most important findings will be summarized and supplemented by recent progress in this area of research. The ER22/23EK polymorphism has repeatedly been associated with a higher risk on developing a depressive episode [48-50], and a faster response after antidepressant treatment [48]. In the study of Bet et al. [50], an association to this polymorphism and clinically relevant depressive symptoms in an elderly population was only found in combination with childhood adversity, indicating a gene-environment interaction. Recently, attention has been directed to the $9 \beta$ SNP in relation to mood. In a sample of 245 bipolar patients, we found an association between the $9 \beta$ polymorphism and reduced risk of (hypo)mania. In the aforementioned study of Bet et al., a relationship between this SNP and clinically relevant depressive symptoms, in combination with childhood adversity, was found [50]. Recently, in a sample of 173 patients with bipolar I depressive episodes, the response to lamotrigine (anti-epileptic medication used in treatment of bipolar depression) in a subgroup of 88 patients was associated with the GR polymorphisms rs258747 and rs6198 (9ß) [52]. Finally, in a group of 526 outpatients with coronary heart disease, the prevalence of depression was increased with an allele-dosage effect (from $24.4 \%$ of the noncarriers to $52.9 \%$ of the homozygous $9 \beta$ carriers) [53]. The BclI polymorphism is also associated with an increased risk on developing a depressive episode [48, 54-56], as well as with a reduced response after antidepressant treatment [54], which was not confirmed by Lee et al. [56]. Remarkably, in the latter study, it was found that in the Korean population there were no carriers of ER22/23EK and N363S. This is consistent with other reports in Asian populations [57].

\section{MR Polymorphisms}

Two SNPs in the MR gene are known to have clinical consequences. The V allele in the MRI180V SNP is associated with higher cortisol levels in saliva and plasma in healthy subjects performing the Trier Social Stress Test (a validated psychological procedure inducing acute stress under laboratory circumstances, allowing evaluation of biological measurements of differences in stress levels between individuals). In vitro testing, using transactivational assays, this $1180 \mathrm{~V}$ variant was shown to have a slight loss of function using cortisol as a ligand [58]. This SNP was associated with higher frequency of depressive symptoms in an elderly cohort (participants aged $>85$ years) [59] and with neuroticism in depressed patients [60]. Another MR SNP, the $-2 \mathrm{G} / \mathrm{C}$ variant, also affects the transactivational capacity of the MR in vitro in response to cortisol. Both SNPs modified cortisol suppression in a DST (0.25 mg DEX) in a sex-specific manner [61].

\section{FKBP5 and CRH-R1 Polymorphisms}

An important co-chaperone protein functionally interacting with the GR is FK506 binding protein 5, better known as FKBP5, a member of the immunophilin protein family. Genetic variations in the FKBP5 gene lead to increased intracellular FKBP5 protein expression, which in turn leads to adaptation of the GR function. Healthy subjects carrying these SNPs show GR resistance and diminished negative feedback of the HPA axis. Carriers of these variations have been found to be overrepresented in patients with mood disorders (MDD and BD) and posttraumatic stress disorder [62], as well as respond faster to 
antidepressant treatment [63]. Another gene, which is a key factor in the HPA axis, is the CRH1-receptor (CRH$\mathrm{R} 1)$. This receptor has been considered as a mediator in initiating the stress response. The CRH-R1 is located in the paraventricular nucleus (PVN) of the hypothalamus, the hippocampus as well as widely distributed beyond the hypothalamus. It interacts with a wide range of neurotransmitters, for example, influences the activity of the $5-\mathrm{HT}_{2 \mathrm{~A} / \mathrm{C}}$ receptor $[64,65]$. Several SNPs in the CRH-R1 gene have been recently identified and explored in relation with mood disorders. Liu et al. found an overrepresentation of rs242939 in patients with major depression compared to healthy controls [66]. They also found that rs242941 carriers with major depression and high levels of anxiety responded faster after treatment with fluoxetine in 127 Han Chinese patients [67]. This was not confirmed by Dong et al. [68] in a population of 536 unrelated Mexican Americans from Los Angeles. In male suicide attempters, a relation between illness severity and a haplotype of the CRHR1 has been found [69], as well as in their offspring with CRH-R1 haplotypes, who were found to score higher on the Beck Depression Inventory, which was found in the same study.

Interestingly, these SNPs in the CRHR1 gene are also studied in relation with the environment and with other genes. Experiencing childhood abuse leads to a higher risk for developing a lifetime depressive episode specifically in carriers of polymorphisms of the CRH-R1 in combination with the short serotonin transporter gene 5-HTTLPR [70]. In parallel, Bradley et al. [71] found an interaction between SNPS in the CRHR1 gene and childhood abuse as predictor for depressive episodes. In one cohort of more than 1,000 female participants, Polanczyk et al. [72] found that carriers of a haplotype formed by rs7209436, rs110402, and rs242924 who were abused during childhood as measured by the Childhood Trauma Questionnaire (CTQ), are protected against depression in adulthood. This was not replicated in another cohort described in the same study, where childhood abuse was not measured by the CTQ.

A recent review by Binder and Nemeroff [64] extensively summarized the relation between genetics of the $\mathrm{CRH}$ system in relation with psychopathology.

\section{Epigenetics of the HPA Axis: Adversity in Childhood}

The influence of genetic variations in the DNA sequences of HPA axis related genes on mood disorders is clear, but may only be one brick in the building of our

GC Sensitivity in Mood Disorders understanding of mood disorders. Of all other influences, it is important to mention epigenetic changes in regulating the 'set-point' of the HPA axis. Epigenetic changes comprise changes in gene expression which remain stable during cell divisions, but do not affect the DNA sequence itself. Epigenetic changes are heritable and could be caused by changes such as those found in DNA methylation, the modeling of chromatin and the de-acetylation of histones in the DNA.

Several circumstances can lead to epigenetic changes, for example intra-uterine influences and changes in early youth due to childhood adversity. A well-known example of intrauterine effects on health in adulthood is the Dutch Famine Birth Cohort study. Children of the women who were pregnant during the famine in WorldWar II scored lower in mental health, and this effect was repeated in their children's children, suggesting an epigenetic effect [73]. However, there was no relation found with changes in HPA axis regulation [74]. Other studies emphasize the importance of regulation of the HPA axis in utero. Raised GC concentrations during pregnancy are associated with lower birth weight and later during childhood and adulthood with an increased cortisol response during HPA axis activation [75]. As a consequence, these patients are at higher risk to develop obesity and/or diabetes. Yehuda et al. [76] reported that women who were pregnant during the World Trade Center attack and developed posttraumatic stress disorder had lower salivary cortisol levels than did their 1-yearold offspring, suggesting they had already developed a risk factor for posttraumatic stress disorder in later life. Animal studies show that prenatal stressed offspring developed hyperactivation of the HPA axis through epigenetic programming, and develop high anxiety levels and depression-like behavior [77, 78].

In early childhood, the regulation of the HPA axis is further developed. Early life trauma could have devastating consequences for the HPA axis 'set-point'. In a recent review, the relation between early life trauma and the HPA axis is characterized by hypocortisolism and an attenuated cortisol response during acute stress [79], which suggests a dysregulation of the negative feedback mechanism in the HPA axis. This diminished stress response is continued throughout life and tends to worsen with aging [80]. Animal studies have shown that mouse pups that have been separated for several days from their mothers have an increased GR expression in frontal cortical and hippocampal areas during the separation. After the separation they showed a diminished GR expression [81]. In humans, this was recently confirmed

Neuroendocrinology 2012;95:179-186 
by McGowan et al. [82], showing that suicide victims with a history of childhood abuse had decreased GR mRNA levels in the hippocampus, as well as increased cytosine methylation of the GR. Secure attachment is a central theme in the work of Bowlby and Ainsworth. The 'strange situation' is a classic test, comprising a short separation between mother and child. After reunion the response of the child towards the mother is categorized in attachment styles, reflecting the involvement or neglect/abuse of the mother for her child [83]. Neglect by the mother is devastating for the development of a secure attachment style of the child, with definite changes (e.g. alterations of methylation pattern of the GR) for the rest of its life.

\section{Conclusive Remarks}

In conclusion, while accumulating evidence indicates that alterations in the HPA axis are important biological factors in mood disorders, the exact pathophysiological mechanisms are at present not completely understood. This is partly due to the difficulties in assessing the HPA axis. One of the promising future techniques could be the assessment of the long-term cortisol levels through analysis of scalp hairs. The 'set-point' of the HPA axis is influenced by genetic changes in the GR gene, MR gene, $\mathrm{CRH}-\mathrm{R} 1$ gene and FKBP5 gene, as well as polymorphisms in other genes involved in cortisol signaling. These changes have been associated with mood disturbances. During life this set-point is further defined by epigenetic changes due to intrauterine influences and/or childhood adversity. Finally, during life this set-point could be influenced by mood episodes. As a result, hyperactivity of the HPA axis may increase the vulnerability for future mood episodes.

Future research should focus on new tools in order to obtain a clear indication of an individual's cortisol status. This may provide better opportunities to understand possible causal relationships between cortisol exposure (in the brain) and mood disorders which may yield new treatment strategies.

\section{References}

1 Patel PD, Lopez JF, Lyons DM, Burke S, Wallace M, Schatzberg AF: Glucocorticoid and mineralocorticoid receptor mRNA expression in squirrel monkey brain. J Psychiatr Res 2000;34:383-392.

$>2$ de Kloet ER, Joels M, Holsboer F. Stress and the brain: from adaptation to disease. Nat Rev Neurosci 2005;6:463-475.

3 Pratt WB, Toft DO. Steroid receptor interactions with heat shock protein and immunophilin chaperones. Endocr Rev 1997;18 306-360.

4 Wust S, Wolf J, Hellhammer DH, Federenko I, Schommer N, Kirschbaum C: The cortisol awakening response - normal values and confounds. Noise Health 2000;2:79-88.

-5 Vreeburg SA, Kruijtzer BP, van Pelt J, van Dyck R, DeRijk RH, Hoogendijk WJG, Smit JH, Zitman FG, Penninx BWJH: Associations between sociodemographic, sampling and health factors and various salivary cortisol indicators in a large sample without psychopathology. Psychoneuroendocrinology 2009;34:1109-1120.

-6 Chida Y, Steptoe A: Cortisol awakening response and psychosocial factors: a systematic review and meta-analysis. Biol Psychol 2009;80:265-278.

7 Vreeburg SA, Hoogendijk WJ, van PJ, DeRijk $\mathrm{RH}$, Verhagen JC, van Dijck R, Smit JH, Zitman FG, Penninx BW: Major depressive disorder and hypothalamic-pituitary-adrenal axis activity: results from a large cohort study. ArchGenPsychiatry. 2009;66:617-626.
8 Bhagwagar Z, Hafizi S, Cowen PJ: Increased salivary cortisol after waking in depression. Psychopharmacology (Berl) 2005; 182 54-57.

$\checkmark 9$ Adam EK, Doane LD, Zinbarg RE, Mineka S, Craske MG, Griffith JW: Prospective prediction of major depressive disorder from cortisol awakening responses in adolescence. Psychoneuroendocrinology 2010;35:921-931.

10 Vreeburg SAH, Catharina A, Hoogendijk WJG, van Dyck R, Zitman FG, Ormel J, Penninx BWJH: Parental history of depression or anxiety and the cortisol awakening response. Br J Psychiatry 2010;197:180-185.

11 Huizenga NA, Koper JW, de Lange P, Pols HA, Stolk RP, Grobbee DE, de Jong FH, Lamberts SW: Interperson variability but intraperson stability of baseline plasma cortisol concentrations, and its relation to feedback sensitivity of the hypothalamopituitary-adrenal axis to a low dose of dexamethasone in elderly individuals. J Clin Endocrinol Metab 1998;83:47-54.

12 Nelson JC, Davis JM: DST studies in psychotic depression: a meta-analysis. Am J Psychiatry 1997;154:1497-1503.

13 Arana GW, Baldessarini RJ, Ornsteen M: The dexamethasone suppression test for diagnosis and prognosis in psychiatry: commentary and review. Arch Gen Psychiatry 1985;42:1193-1204.

14 Heuser I, Yassouridis A, Holsboer F: The combined dexamethasone/CRH test: a refined laboratory test for psychiatric disorders. J Psychiatr Res 1994;28:341-356.
15 Zobel AW, Nickel T, Sonntag A, Uhr M, Holsboer F, Ising M: Cortisol response in the combined dexamethasone/CRH test as predictor of relapse in patients with remitted depression: a prospective study. J Psychiatr Res 2001;35:83-94.

16 Appelhof BC, Huyser J, Verweij M, Brouwer JP, van Dyck R, Fliers E, Hoogendijk WJG, Tijssen JGP, Wiersinga WM, Schene AH: Glucocorticoids and relapse of major depression (dexamethasone/corticotropin-releasing hormone test in relation to relapse of major depression). Biol Psychiatry 2006;59:696-701.

17 Ising M, Horstmann S, Kloiber S, Lucae S, Binder EB, Kern N, Kunzel HE, Pfennig A, Uhr M, Holsboer F: Combined dexamethasone/corticotropin releasing hormone test predicts treatment response in major depression - a potential biomarker? Biol Psychiatry 2007;62 47-54.

18 Watson S, Gallagher P, Ritchie JC, Ferrier IN, Young AH: Hypothalamic-pituitary-adrenal axis function in patients with bipolar disorder. Br J Psychiatry 2004;184496-184502.

19 Ellenbogen MA, Santo JB, Linnen AM, Walker CD, Hodgins S: High cortisol levels in the offspring of parents with bipolar disorder during two weeks of daily sampling. Bipolar Disord 2010;12:77-86.

20 Wichers M, Geschwind N, van Os J, Peeters F: Scars in depression: is a conceptual shift necessary to solve the puzzle? Psychol Med 2010;40:359-365. 
21 Poulter MO, Du L, Weaver ICG, Palkovits M, Faludi G, Merali Z, Szyf M, Anisman H: GABA-A receptor promoter hypermethylation in suicide brain: implications for the involvement of epigenetic processes. Biol Psychiatry 2008;64:645-652.

-22 Oberlander TF, Weinberg J, Papsdorf M, Grunau R, Misri S, Devlin AM: Prenatal exposure to maternal depression, neonatal methylation of human glucocorticoid receptor gene (NR3C1) and infant cortisol stress responses. Epigenetics 2008;3:97-106.

23 Van Uum SH, Sauve B, Fraser LA, MorleyForster P, Paul TL, Koren G: Elevated content of cortisol in hair of patients with severe chronic pain: a novel biomarker for stress. Stress 2008;11:483-488.

-24 Kirschbaum C, Tietze A, Skoluda N, Dettenborn L: Hair as a retrospective calendar of cortisol production-Increased cortisol incorporation into hair in the third trimester of pregnancy. Psychoneuroendocrinology 2009;34:32-37.

25 Koper JW, Manenschijn L, Lamberts SW, Van Rossum EFC: Evaluation of a method to measure long term cortisol levels. Steroids 2011;doi:10.1016/j.steroids.2011.04.005.

26 Steudte S, Dettenborn L, Klumbies E, Foley P, Beesdo-Baum KCK: Decreased hair cortisol concentrations in generalised anxiety disorder. Psychiatry Res 2010; Epub ahead of print.

27 Manenschijn L, Spijker AT, Jetten AM, Hoencamp E, Van Rossum EFC: Evaluation of a method to measure long term cortisol levels in health and bipolar disorder. Tijdschr Psychiatr 2011;(suppl 1331).

28 Spijker AT, Manenschijn L, Koenders M, Jetten AM, Haffmans J, Hoencamp E, van Rossum EFC: Cortisol levels in scalp hair in relation to age of onset and cognition in patients with Bipolar Disorder. Tijdschr Psychiatr 2011;(suppl 1330)

-29 Manenschijn L, van den Akker EL, Lamberts SW, van Rossum EF: Clinical features associated with glucocorticoid receptor polymorphisms: an overview. Ann NY Acad Sci 2009; 1179:179-198.

- 30 Derijk RH, Schaaf MJ, Turner G, Datson NA, Vreugdenhil E, Cidlowski J, de Kloet ER Emery P, Sternberg EM, Detera-Wadleigh SD: A human glucocorticoid receptor gene variant that increases the stability of the glucocorticoid receptor beta-isoform mRNA is associated with rheumatoid arthritis. J Rheumatol 2001;28:2383-2388.

-31 van Rossum EFC, Koper JW, Huizenga NATM, Uitterlinden AG, Janssen JAMJL, Brinkmann AO, Grobbee DE, de Jong FH, van Duyn CM, Pols HAP, Lamberts SWJ: A polymorphism in the glucocorticoid receptor gene, which decreases sensitivity to glucocorticoids in vivo, is associated with low insulin and cholesterol levels. Diabetes 2002; 51:3128-3134.
32 van Rossum EF, Lamberts SW: Polymorphisms in the glucocorticoid receptor gene and their associations with metabolic parameters and body composition. Recent Prog Horm Res 2004;593:33-57.

33 van den Akker EL, Russcher H, van Rossum EF, Brinkmann AO, de Jong FH, Hokken A, Pols HA, Koper JW, Lamberts SW: Glucocorticoid receptor polymorphism affects transrepression but not transactivation. J Clin EndocrinolMetab 2006;91:2800-2803.

- 34 van Rossum EF, Feelders RA, van den Beld AW, Uitterlinden AG, Janssen JA, Ester W, Brinkmann AO, Grobbee DE, de Jong FH, Pols HA, Koper JW, Lamberts SW: Association of the ER22/23EK polymorphism in the glucocorticoid receptor gene with survival and C-reactive protein levels in elderly men. Am J Med 2004;117:158-162.

35 van Rossum EF, Lamberts SW: Polymorphisms in the glucocorticoid receptor gene and their associations with metabolic parameters and body composition. Recent Prog Horm Res 2004;59:333-357.

36 Bertalan R, Patocs A, Boyle B, Rigo J, Racz $\mathrm{K}$ : The protective effect of the ER22/23EK polymorphism against an excessive weight gain during pregnancy. Gynecol Endocrinol 2009;25:379-382.

37 Russcher H, Smit P, van den Akker EL, van Rossum EF, Brinkmann AO, de Jong FH, Lamberts SW, Koper JW: Two polymorphisms in the glucocorticoid receptor gene directly affect glucocorticoid-regulated gene expression. J Clin Endocrinol Metab 2005; 90:5804-5810.

- 38 Russcher H, van Rossum EF, de Jong FH, Brinkmann AO, Lamberts SW, Koper JW: Increased expression of the glucocorticoid receptor-A translational isoform as a result of the ER22/23EK polymorphism. Mol Endocrinol 2005; 19:1687-1696.

-39 van Oosten MJM, Dolhain RJEM, Koper JW, van Rossum EFC, Emonts M, Han $\mathrm{KH}$, Wouters JMGW, Hazes JMW, Lamberts SWJ, Feelders RA: Polymorphisms in the glucocorticoid receptor gene that modulate glucocorticoid sensitivity are associated with rheumatoid arthritis. Arthritis Res Ther 2010;12:R159.

40 van Winsen LM, Manenschijn L, van Rossum EF, Crusius JB, Koper JW, Polman CH, Uitdehaag BM: A glucocorticoid receptor gene haplotype (TthIII1/ER22/23EK/9beta) is associated with a more aggressive disease course in multiple sclerosis. J Clin Endocrinol Metab 2009;94:2110-2114.

41 van den Akker EL, Koper JW, van Rossum EF, Dekker MJ, Russcher H, de Jong FH, Uitterlinden AG, Hofman A, Pols HA, Witteman JC, Lamberts SW: Glucocorticoid receptor gene and risk of cardiovascular disease. Arch Intern Med 2008;168:33-39.

42 Otte C, Wust S, Zhao S, Pawlikowska L, Kwok P-Y, Whooley MA: Glucocorticoid receptor gene, low-grade inflammation, and heart failure: the Heart and Soul study. J Clin Endocrinol Metab 2010;95:2885-2891.
43 van Rossum EF, Koper JW, van den Beld AW, Uitterlinden AG, Arp P, Ester W, Janssen JA, Brinkmann AO, de Jong FH, Grobbee DE, Pols HA, Lamberts SW: Identification of the BclI polymorphism in the glucocorticoid receptor gene: association with sensitivity to glucocorticoids in vivo and body mass index. Clin Endocrinol (Oxf) 2003;59:585-592.

44 Rosmond R, Holm G: A 5-year follow-up study of 3 polymorphisms in the human glucocorticoid receptor gene in relation to obesity, hypertension, and diabetes. J Cardiometab Syndr 2008;3:132-135.

45 Szappanos A, Patocs A, Toke J, Boyle B, Sereg M, Majnik J, Borgulya G, Varga I, Liko I, Racz K, Toth M: BclI polymorphism of the glucocorticoid receptor gene is associated with decreased bone mineral density in patients with endogenous hypercortisolism. Clin Endocrinol (Oxf) 2009;71:636-643.

46 Voorhoeve PG, van den Akker ELT, van Rossum EFC, Koper JW, van Mechelen W, Lamberts SWJ, Delemarre-van de Waal HA: Glucocorticoid receptor gene variant is associated with increased body fatness in youngsters. Clin Endocrinol (Oxf) 2009;71: 518-523.

47 Spijker AT, van Rossum EFC: Glucocorticoid receptor polymorphisms in major depression: focus on glucocorticoid sensitivity and neurocognitive functioning. Ann NY Acad Sci 2009;1179199-1179215.

48 van Rossum EFC, Binder EB, Majer M, Koper JW, Ising M, Modell S, Salyakina D, Lamberts SWJ, Holsboer F: Polymorphisms of the glucocorticoid receptor gene and major depression. Biol Psychiatry 2006;59:681688.

49 Van West D, Van Den EF, Del-Favero J, Souery D, Norrback KF, Van DC, Sluijs S, Adolfsson R, Mendlewicz J, Deboutte D, Van BC, Claes S: Glucocorticoid receptor genebased SNP analysis in patients with recurrent major depression. Neuropsychopharmacology 2006;31:620-627.

50 Bet PM, Penninx BWJH, Bochdanovits Z, et al: Glucocorticoid receptor gene polymorphisms and childhood adversity are associated with depression: new evidence for a gene-environment interaction. Am J Med Genet B Neuropsychiatr Genet 2009;150B: 660-669.

51 Spijker AT, van Rossum EF, Hoencamp E, DeRijk RH, Haffmans J, Blom M, Manenschijn L, Koper JW, Lamberts SW, Zitman FG: Functional polymorphism of the glucocorticoid receptor gene associates with mania and hypomania in bipolar disorder. Bipolar Disord. 2009;11:95-101.

52 Perlis RH, Adams DH, Fijal B, Sutton VK, Farmen M, Breier A, Houston JP: Genetic association study of treatment response with olanzapine/fluoxetine combination or lamotrigine in bipolar I depression. J Clin Psychiatry 2010;71:599-605. 
53 Otte C, Wüst S, Zhao S, Pawlikowska L, Kwok PY, Whooley MA: Glucocorticoid receptor gene and depression in patients with coronary heart disease: the Heart and Soul Study - 2009 Curt Richter Award Winner. Psychoneuroendocrinology 2009;34:15741581.

-54 Brouwer JP, Appelhof BC, van Rossum EFC, Koper JW, Fliers E, Huyser J, Schene AH, Tijssen JGP, Van Dyck R, Lamberts SWJ, Wiersinga WM, Hoogendijk WJG: Prediction of treatment response by HPA axis and glucocorticoid receptor polymorphisms in major depression. Psychoneuroendocrinology 2006;31:1154-1163.

55 Krishnamurthy P, Romagni P, Torvik S, Gold PW, Charney DS, tera-Wadleigh S, Cizza G: Glucocorticoid receptor gene polymorphisms in premenopausal women with major depression. Horm Metab Res 2008;40: 194-198.

-56 Lee HY, Kang RH, Han SW, Paik JW, Chang HS, Jeong YJ, Lee MS: Association of glucocorticoid receptor polymorphisms with the susceptibility to major depressive disorder and treatment responses in Korean depressive patients. Acta Neuropsychiatr 2009;21: 11-17.

57 Duan Z-X, Gu W, Du D-y, Hu P, Jiang D-p, Zhu P-F, Wang Z-G, Jiang J-X: Distributions of glucocorticoid receptor gene polymorphisms in a Chinese Han population and associations with outcome after major trauma. Injury 2009;40:479-483.

58 DeRijk RH, Wüst S, Meijer OC, Zennaro MC, Federenko IS, Hellhammer DH, Giacchetti G VE, Zitman FG, de Kloet ER: A common polymorphism in the mineralocorticoid receptor modulates stress responsiveness. J Clin Endocrinol Metab 2006;12: 5083-5089.

59 Kuningas M, de Rijk RH, Westendorp RG, Jolles J, Slagboom PE, van Heemst D: Mental performance in old age dependent on cortisol and genetic variance in the mineralocorticoid and glucocorticoid receptors. Neuropsychopharmacology 2007;32:1295-12301.

60 DeRijk RH, de Kloet ER, Zitman FG, van Leeuwen N: Mineralocorticoid receptor gene variants as determinants of HPA axis regulation and behavior. Endocr Dev 2011;2013720148.

-61 van Leeuwen N, Kumsta R, Entringer S, de Kloet ER, Zitman FG, DeRijk RH, Wüst S: Functional mineralocorticoid receptor (MR) gene variation influences the cortisol awakening response after dexamethasone. Psychoneuroendocrinology 2010;35:339-349.

62 Binder EB: The role of FKBP5, a co-chaperone of the glucocorticoid receptor in the pathogenesis and therapy of affective and anxiety disorders. Psychoneuroendocrinology 2009;34(suppl 1):S186-S195.
63 Binder EB, Salyakina D, Lichtner P, et al: Polymorphisms in FKBP5 are associated with increased recurrence of depressive episodes and rapid response to antidepressant treatment. Nat Genet 2004;36:1319-1325.

64 Binder EB, Nemeroff CB: The CRF system, stress, depression and anxiety - insights from human genetic studies. Mol Psychiatry 2010;15:574-588.

65 Magalhaes AC, Holmes KD, Dale LB, Comps-Agrar L, Lee D, Yadav PN, Drysdale L, Poulter MO, Roth BL, Pin J-P, Anisman H, Ferguson SSG: CRF receptor 1 regulates anxiety behavior via sensitization of 5-HT2 receptor signaling. Nat Neurosci 2010;13: 622-629.

66 Liu Z, Zhu F, Wang G, Xiao Z, Wang H, Tang J, Wang X, Qiu D, Liu W, Cao Z, Li W: Association of corticotropin-releasing hormone receptor 1 gene SNP and haplotype with major depression. Neurosci Lett 2006;404:358362.

67 Liu Z, Zhu F, Wang G, Xiao Z, Tang J, Liu W, Wang $\mathrm{H}$, Liu $\mathrm{H}$, Wang X, Wu Y, Cao Z, Li W: Association study of corticotropin-releasing hormone receptorl gene polymorphisms and antidepressant response in major depressive disorders. Neurosci Lett 2007;414: 155-158.

68 Dong C, Wong ML, Licinio J: Sequence variations of ABCB1, SLC6A2, SLC6A3, SLC6A4, CREB1, CRHR1 and NTRK2: association with major depression and antidepressant response in Mexican-Americans. Mol Psychiatry 2009;14:1105-1118.

69 Wasserman D, Wasserman J, Rozanov V, Sokolowski M: Depression in suicidal males: genetic risk variants in the CRHR1 gene. Genes Brain Behav 2009;8:72-79.

-70 Ressler KJ, Bradley B, Mercer KB, Deveau TC, Smith AK, Gillespie CF, Nemeroff CB, Cubells JF, Binder EB: Polymorphisms in CRHR1 and the serotonin transporter loci: gene $\times$ gene $\times$ environment interactions on depressive symptoms. Am J Med Genet 2010; 153B:812-824.

71 Bradley RG, Binder EB, Epstein MP, Tang Y, Nair HP, Liu W, Gillespie CF, Berg T, Evces M, Newport DJ, Stowe ZN, Heim CM, Nemeroff CB, Schwartz A, Cubells JF, Ressler KJ: Influence of child abuse on adult depression: moderation by the corticotropin-releasing hormone receptor gene. Arch Gen Psychiatry 2008;65:190-200.

72 Polanczyk G, Caspi A, Williams B, Price TS, Danese A, Sugden K, Uher R, Poulton R, Moffitt TE: Protective effect of CRHR1 gene variants on the development of adult depression following childhood maltreatment: replication and extension. Arch Genl Psychiatry 2009;66:978-985.

73 Stein AD, Pierik FH, Verrips GHW, Susser ES, Lumey LH: Maternal exposure to the Dutch famine before conception and during pregnancy: quality of life and depressive symptoms in adult offspring. Epidemiology 2009;20:909-915.
4 de Rooij SR, Painter RC, Phillips DIW, Osmond C, Tanck MWT, Bossuyt PMM, Roseboom TJ: Cortisol responses to psychological stress in adults after prenatal exposure to the Dutch famine. Psychoneuroendocrinology 2006;31:1257-12.

75 Reynolds RM: Corticosteroid-mediated programming and the pathogenesis of obesity and diabetes. J Steroid Biochem Mol Biol 2010;122:3-9.

76 Yehuda R, Engel SM, Brand SR, Seckl J, Marcus SM, Berkowitz GS: Transgenerational effects of posttraumatic stress disorder in babies of mothers exposed to the World Trade Center attacks during pregnancy. J Clin Endocrinol Metab 2005;90:4115-411

77 Abe H, Hidaka N, Kawagoe C, Odagiri K, Watanabe Y, Ikeda T, Ishizuka Y, Hashiguchi H, Takeda R, Nishimori T, Ishida Y: Prenatal psychological stress causes higher emotionality, depression-like behavior, and elevated activity in the hypothalamo-pituitary-adrenal axis. Neurosci Res 2007;59:145-11.

78 Darnaudery M, Maccari S: Epigenetic programming of the stress response in male and female rats by prenatal restraint stress. Brain Res Rev 2008;57:571-585.

79 Yehuda R, Flory JD, Pratchett LC, Buxbaum J, Ising M, Holsboer F: Putative biological mechanisms for the association between early life adversity and the subsequent development of PTSD. Psychopharmacology (Berl) 2010;212:405-417.

80 Carpenter LL, Tyrka AR, Ross NS, Khoury L, Anderson GM, Price LH: Effect of childhood emotional abuse and age on cortisol responsivity in adulthood. Biol Psychiatry 2009;66: 69-75.

81 Navailles S, Zimnisky R, Schmauss C: Expression of glucocorticoid receptor and early growth response gene 1 during postnatal development of two inbred strains of mice exposed to early life stress. Dev Neurosci 2010; 32:139-148.

82 McGowan PO, Sasaki A, D’Alessio AC, Dymov S, Labonte B, Szyf M, Turecki G, Meaney MJ: Epigenetic regulation of the glucocorticoid receptor in human brain associates with childhood abuse. Nat Neurosci 2009;12:342-348.

83 Bretherton I: The origins of attachment theory: John Bowlby and Mary Ainsworth. Dev Psychol 1992;28:759-775.

84 Rybakowski JK, Twardowska K: The dexamethasone/corticotropin-releasing hormone test in depression in bipolar and unipolar affective illness. J Psychiatr Res 1999;33:363-370. 